rhinoceros area ; to Circle Officer Captain Tej Jung Thapa, an experienced sportsman and naturalist ; to Major Lok Bikram, who helped me to obtain elephants in the Rapti Valley; to Mr. K. B. Malla, Chief of the Rapti Valley Multi-Purpose Project, who kindly allowed me camping facilities and transport to Dadrahani ; to Mr. Boris Lissanevitch, of the Hotel Royal in Katmandu, who very kindly made available to me some camping equipment as well as much information ; to Colonel and Mrs. Proud of the British Embassy, Mr. Sen of the Indian Embassy, and Mr. N. Pal of the India Aid Mission, all of whom showed much interest in my mission.

In particular I want to offer my thanks and appreciation to Mr. Sudhir Jung Thapa, Divisional Forest Officer of Chitawan, who accompanied me during most of my tour in the rhinoceros areas, and without whose patient help and never failing supply of information my work could not have been successful. To Captain Gyan Bahadur Basnayt and Lieutenant Gaj Raj Joshi, officers in charge of the Rhinoceros Protection Department, I owe my gratitude for making all the local arrangements, including camping, elephant trips, etc.

\title{
X. Literature Consulted
}

Blanford, W. T. (1891). The Fauna of British India, Mammalia, Part II.

Shebreare, E. O. (1953). "Status of the Three Asiatic Rhinoceros," Orya, Vol. II, No. 3.

Smythies, E. A. (1942), Big Game Shooting in Nepal.

Smythies, Olive (1953). Tiger Lady.

STraceY, P.D. (1957). "The Status of the Great Indian Rhinoceros (R. unicornis) in Nepal." Journal of the Bombay Natural History Society, August, 1957.

\section{Glossary of Local Terms}

Bhabar : dry country, with a subsoil of boulders, at the foot of the Himalayas.

Bhangala : a channel of a river.

Bheel : a small lake (in Assam).

Chowki : a post, or a hut (for a forest guard, etc.).

Dans : horse-fly or gad-fly.

Dun : a plateau in a valley or a flat valley in the foothills of the Himalayas.

Hatisar : an elephant station.

Khola : a stream.

Sal : a hardwood species of tree of great commercial value.

Savannah: tropical or sub-tropical grassland containing scattered trees or shrubs.

Shikar : shooting, or sport.

Tal : a small lake.

Tand : look-out tower for frightening away crop-raiding rhinoceros and other animals.

Tapoo: an island in a river.

Terai : moist country a few miles from the base of the Himalayas, at the edge of the bhabar.

Tongi : the Assam equivalent of tand. 